\title{
MACRO- AND MICROMORPHOLOGY STUDIES OF THE LEAF, STEM AND STEM BARK OF FICUS PANDURATA HANCE. CULTIVATED IN EGYPT
}

\author{
M. A. Ramadan ${ }^{1}$, A. S. Ahmad ${ }^{1}$, A. M. Nafady ${ }^{2}$ and A. I. Mansour ${ }^{2}$ \\ ${ }^{1}$ Department of Pharmacognosy, Faculty of Pharmacy, Assiut \\ University, Assiut, Egypt \\ ${ }^{2}$ Department of Pharmacognosy, Faculty of Pharmacy, Al-Azhar \\ University, Assiut, Egypt
}

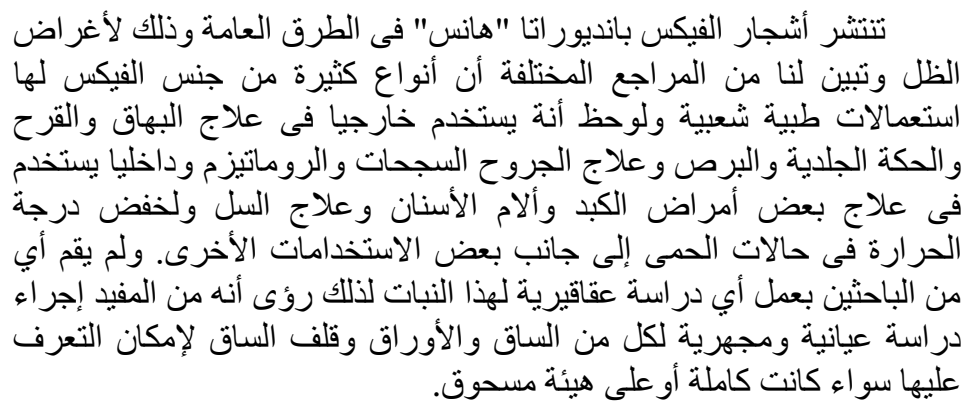

Ficus pandurata (Hance) Fiddle leaf fig (Family, Moraceae) is a tree indigenous to South Africa and cultivated in Egypt for its shade in public and private gardens. Previous investigations of Ficus species showed many medicinal uses; externally they have been used for treatment of leprosy, ulcers, itching, leucoderma and warts. Internally used as anti-inflammatory, to reduce fever, cure tuberculosis and against intestinal parasites. In the present work, the detailed macro-and micromorphological characters of the leaf, stem and stem bark of Ficus pandurata Hance were studied with the aim to find out the diagnostic elements of these organs, which facilitate their identification in both entire and powdered forms.

\section{INTRODUCTION}

The family Moraceae known as mulberry family comprises over 73 genera and 1000 species $^{1-8}$. The plants belonging to this family (trees, shrubs, herbs, or vines, mainly woody) are widely spread in tropical and subtropical regions, less common in temperate areas ${ }^{1-8}$. 
The genus Ficus is a very large genus of at least 800 species and widely spread in tropical and subtropical countries ${ }^{1-8}$.

The statement mentioned in holy book, Koran, about some materials of plant origin have drown, the almighty god, swore with Ficus and Olives in surah of EL-Tin, this may point to the importance of Ficus among the plant kingdom.

Some of Ficus species are grown for their edible fruits, (Ficus sycomorus Linn.), while others for providing shade and as ornamental plants.

In folk medicine, Ficus plants are reported to have hypotensive and antidiabetic activities, also they are used to treat cough, scrofula, chest condition, and also they are used as mild laxative, and antirheumatic, digestive and as anthelmintic against intestinal parasites. It has been used as antiinflammatory in urinary tract, in sore throat, ulcerated nose, to reduce fever, to cure tuberculosis and piles ${ }^{9-11}$.

Externally, they have been used to treat postulous, eczema, to cure tinea, leprosy, to treat cracks in the soles of the feet and dressing to boils. Several Ficus species are indigenous to Egypt, such as Ficus syocomorus Linn., Ficus pseudosycomorus Decene., Ficus salicifolia Vahl., other species are recently introduced, such as Ficus asprima Linn., Ficus benjamina
Linn., Ficus elastica Roxb., Ficus glomerata Roxb., Ficus eriobatriods Linn., Ficus hisptida linn., Ficus infectoria Roxb., Ficus macrophylla Linn., Ficus platiboda Linn., Ficus pareelli Veitch., Ficus religiosa Linn., and Ficus pandurata Hance.

Ficus pandurata Hance (Ficus lyrata), fiddle leaf is indigenous to tropical central and West Africa. It is 5-11 meters tall, evergreen tree of upright-spreading, irregular growth, produces 20 to 38 centimeter long and 25 centimeter wide, dull green, thick, fiddle shaped leaves which are quite attractive, the trunk can grow to several feet thick. Ficus pandurata used as container or above-ground planter, shade tree, suitable for growing indoors ${ }^{12 \& 13}$.

\section{Habitat}

Ficus pandurata (Hance) is a large ever-green tree attaining up to 11 meters in height (Fig. 1). The tree bears simple coriaceous, obovate leaves with cordate or squared basal ends and slightly wavy and scalloped margins. The flowers are inconspicuous and not showy. Fruits are succulent, enlarged hollow, cup-shaped closed receptacles, enclosing achene's-like bodies (syconus); they are yellowish-brown when ripe ${ }^{12 \& 13}$. 


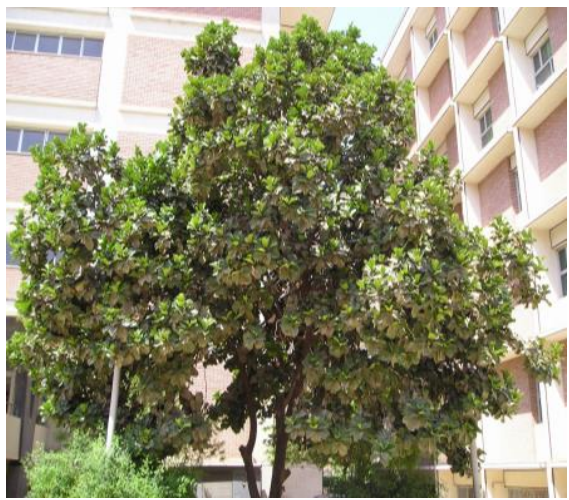

Fig. 1: Photo of the plant.

\section{Materials}

The plant materials used in this work consisted of the separated fresh samples of the separate organs (stems, leaves and stem bark) of Ficus pandurata Hance as well as samples preserved in mixture of alcohol - glycerin - water (1:1:1) and stored in well tightly closed containers. The plant materials were collected in the period from March to April 2004 from the front of Faculty of Pharmacy, Assiut University. The plant was kindly identified and authenticated by Prof. Dr. Salah EL-Nagar (Professor of botany, Faculty of Science, Assiut University). The samples were gathered during flowering and fruiting stages.

\section{Macromorphological study of Ficus pandurata (Hance)}

\section{Macromorphology}

\section{1- The stem: (Figs. 1 \& 3C)}

The main trunk of the plant (Figs. $1 \& 3 \mathrm{C}$ ) is erect, cylindrical, woody mono-podially branched, reaching about 5-11 meters in height and $35-75 \mathrm{~cm}$ in diameter near the base.

The outer surface is dark-brown, rough, wrinkled, showing lenticels, the terminal and lateral branches are thinner, green in color, faintly longitudinally striated and have short internodes (about $2-5 \mathrm{~cm}$ in length), the older lower branches are brown with rough surface and carry scars of fallen leaves. The stems are odorless with a bitter acrid taste.

The bark (Figs. 2B, C \& 3D) is hardly separated from the wood and usually broken into vertical fissures. The outer surface of the bark is dark gray to almost black with longitudinal wrinkles, transverse fissures and lenticels.

\section{2- Leaves: (Figs. 2A \& 3B)}

The leaves are simple, obovate with cordate or squared symmetric bases and slightly wavy and scalloped margins, acuminate apices with very tough and leathery texture. The leaves measure about 18 to $30 \mathrm{~cm}$ in length and 9 to 20 $\mathrm{cm}$ in width. Both surfaces are smooth, shining and glabrous, the upper surface is dark deep glossy green, while the lower one is lighter with prominent midrib and lateral veins. The venation is pinnate. The common name fiddle-leaf fig perfectly describes their shape.

The petiole is nearly cylindrical in shape green, smooth, glabrous 


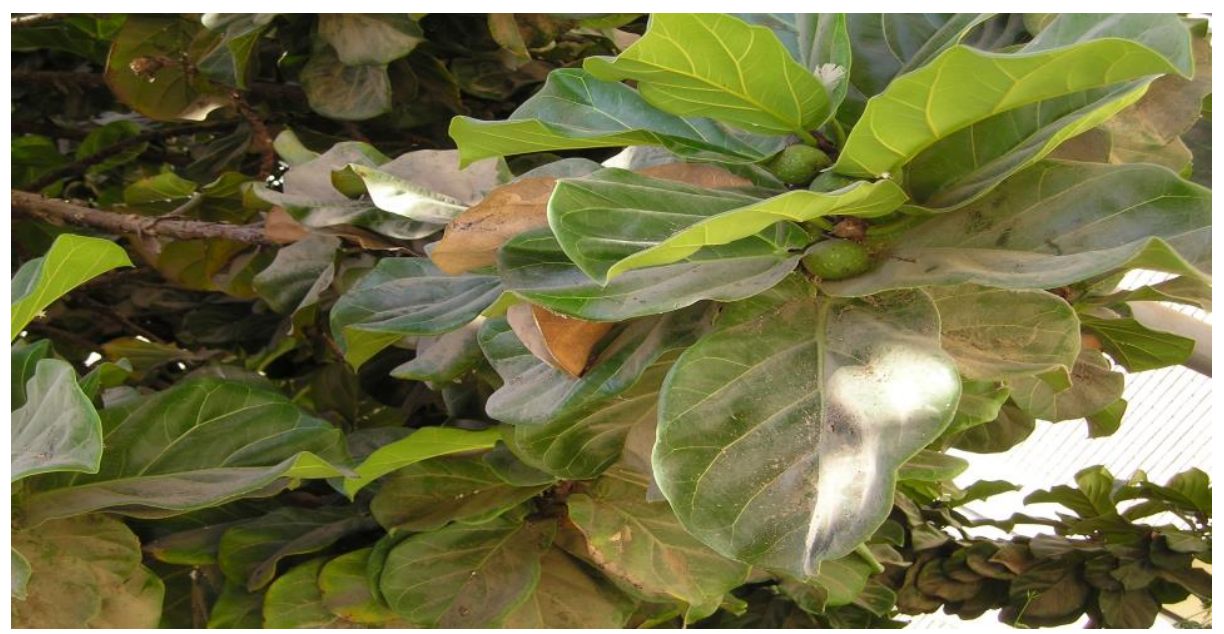

(A)

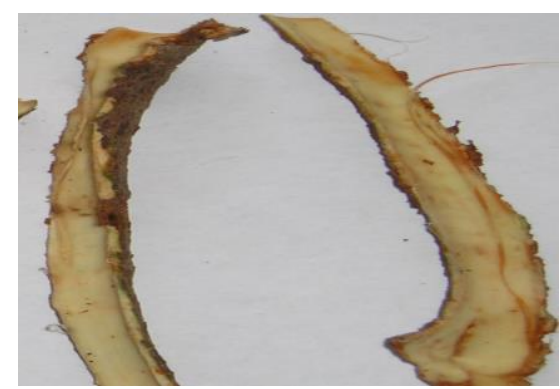

(C)

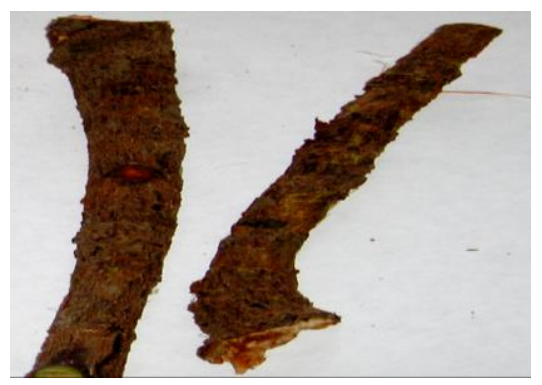

(B)

Fig. 2: A. Photo of the leaves and fruits.

B. Photo of the outer surface of the bark.

C. Photo of the inner surface of the bark. 


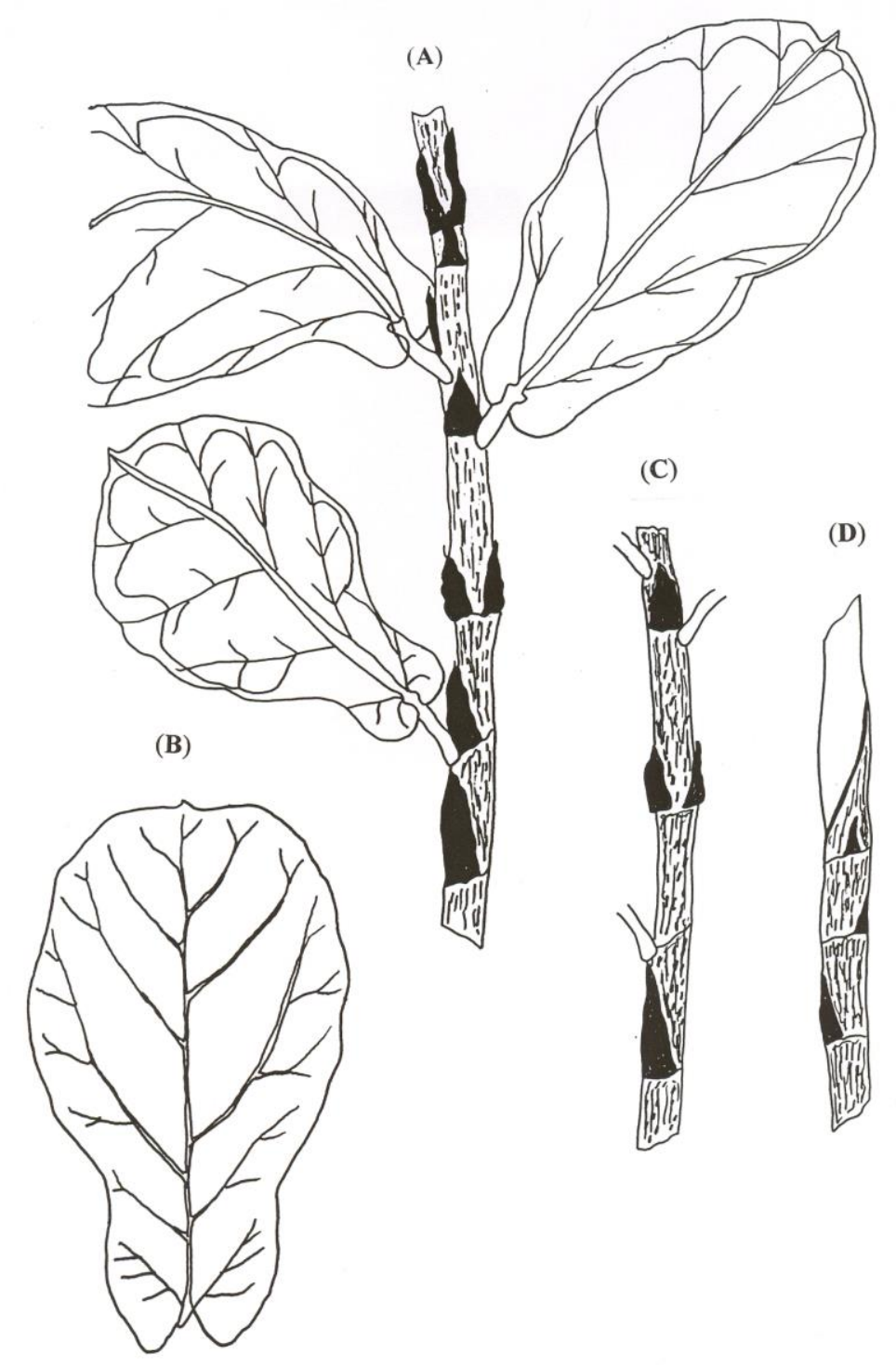

Fig. 3: Macromorphology of the leaf, stem and stem bark.
A. Macromorphology of the branch
$\mathrm{X} 1 / 3$
B. Macromorphology of the leaf
$\mathrm{X} 1 / 3$
C. Macromorphology of the stem
$\mathrm{X} 1 / 3$
D. Macromorphology of the stem bark
$\mathrm{X} 1 / 3$ 
and measures $1.5-2.5 \mathrm{~cm}$ in length and about $0.5-0.7 \mathrm{~cm}$ in diameter. The leaf has faint odour and bitter astringent taste.

\section{Micromorphological study of Ficus pandurata (Hance)}

\section{A- The stem}

\section{1- The young stem}

A transverse section through the young stem (Fig. 4A) is nearly circular in outline. It shows an outer epidermis carrying few hairs and accompanied by one to two layers of hypodermal cells. The cortex consists of complete ring of 2-4 layers of sclerides followed by $5-8$ layers of collenchymatous cells and several layers of parenchymatous cells. The parenchyma cells contain prismatic and cluster crystals of calcium oxalate. Starch granules are also observed. The endodermis is indistinct.

The pericycle consists of groups of lignified fibers alternating with parenchyma. The vascular tissue consists of a continuous ring of outer phloem and inner radiating xylem both are traversed by medullary rays. The pith is formed of wide parenchymatous cells somewhat lignified near to the xylem and some of them have pitted walls.

\section{The epidermis: (Figs. 4C \& 5)}

In transverse section the epidermis appears as one layer of polygonal cells, covered with thick smooth cuticle, in surface view (Fig.
4C), the cells are polygonal, somewhat elongated with straight anticlinal walls and measure (16-2330) $\mu$ in length, (12-17-21) $\mu$ in width and (7- $-9-9) \mu$ in height, stomata were not observed, few unicellular non-glandular hairs were observed which covered with thick smooth cuticle and contain brownish matter, it measure (37-6184) $\mu$ in length and (7-10-13) $\mu$ in width.

The epidermal cells are followed by two rows of polyhedral to subrectangular sub epidermal parenchyma cells (hypodermis).

\section{The cortex: (Fig. 5)}

It is formed of a complete ring of about 2-4 layers of lignified sclerides with thick walled moderately wide lumina and measure about (12-24-35) $\mu$ in length and (12-16-19) $\mu$ in width as shown in the isolated elements, followed by 5-8 layers of more or less rounded to oval collenchymatous cells.

The parenchyma cells of the cortex contain prismatic and cluster crystals of calcium oxalate. The prism measures (5-9-13) $\mu$ in length and the cluster measures (9-13-17) $\mu$ in diameter. Some of the cortical cells contain starch granules which are oval to rounded, mostly simple; few are compound of of 2-3 components and measuring (3-4-5) $\mu$ in diameter. The endodermis is indistinct. 
(A)

n.gl.h.

(B)

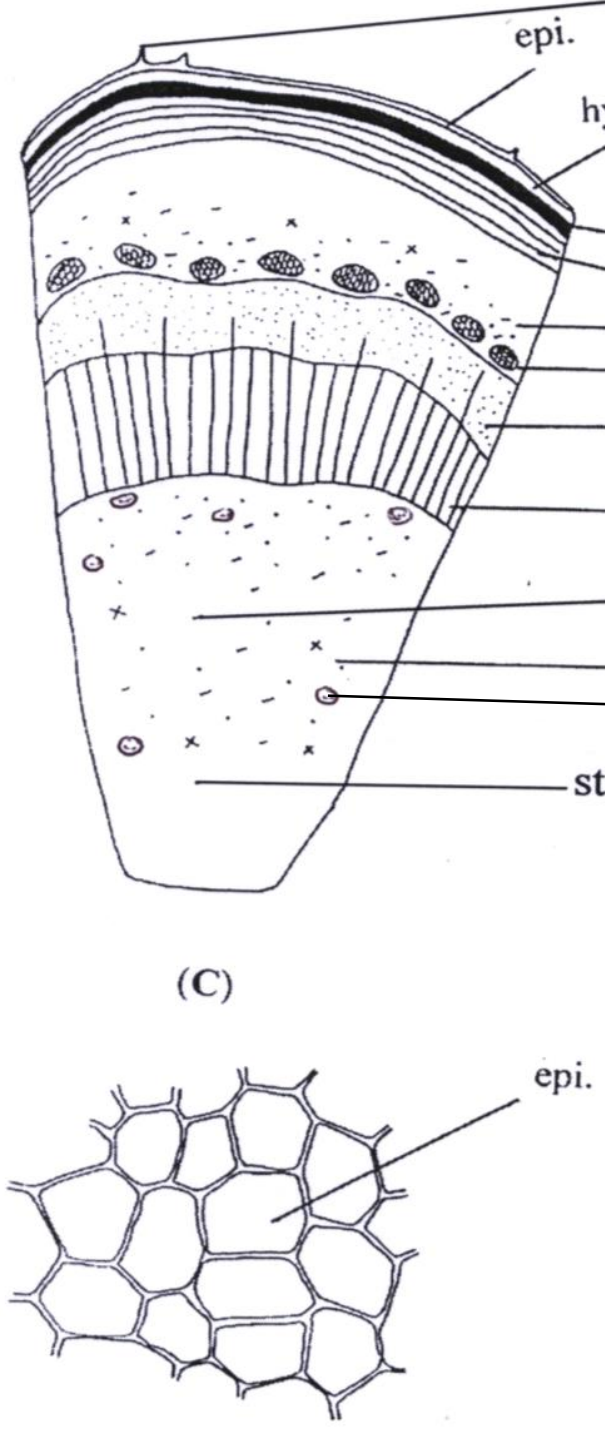

st.gr.

pi.

ca.ox.

ck.

scl.

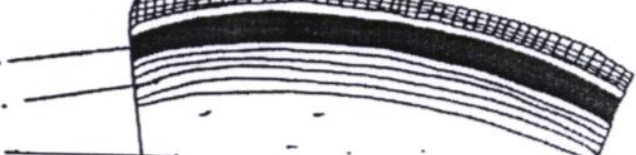

cor.

pe.

ph.

xyl.

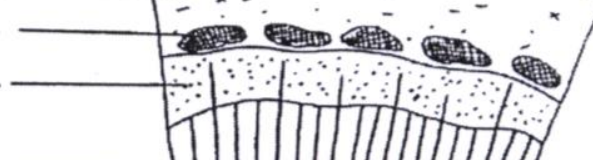

int.ph

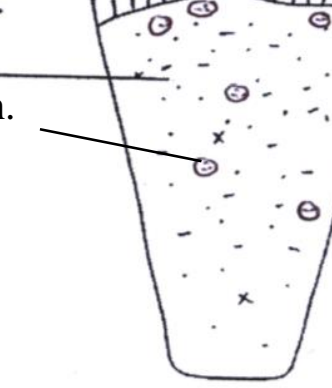

(D)

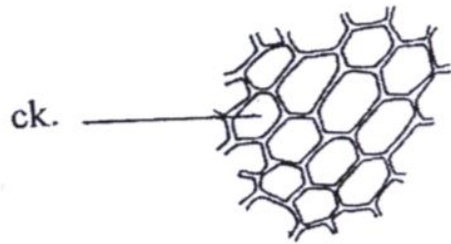

B. Diagrammatic T. S of old stem

X 62.5

C. Surface preparation of young stem

X 500

D. Cork cells

X 500

ca.ox., calcium oxalate; ck., cork; coll., collenchyma; cor., cortex; epi., epidermis; int.ph., intraxylary phloem: hvno. hvnodarmic. n -1 .
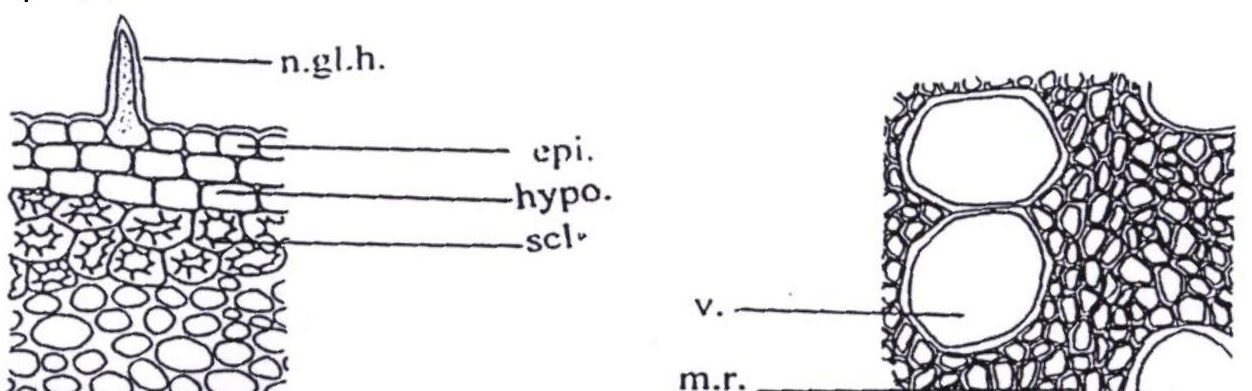
xyl.v.

int.ph

int.ph

Fig. 5: Detailed T.S. of the young stem

ca.ox., calcium oxalate; cam., cambium; coll., collenchyma; hypo., hypodermis; epi.,epidermis; int.ph., intraxylary phloem; 1.v., laticiferous vessel; m.r., medullary ray; n.gl.h., non glandular hair; par., parenchyma; ph., phloem; p.f., pericyclic fiber; pi., pith; st.gr., starch granules; xyl.v., xylem vessel. 

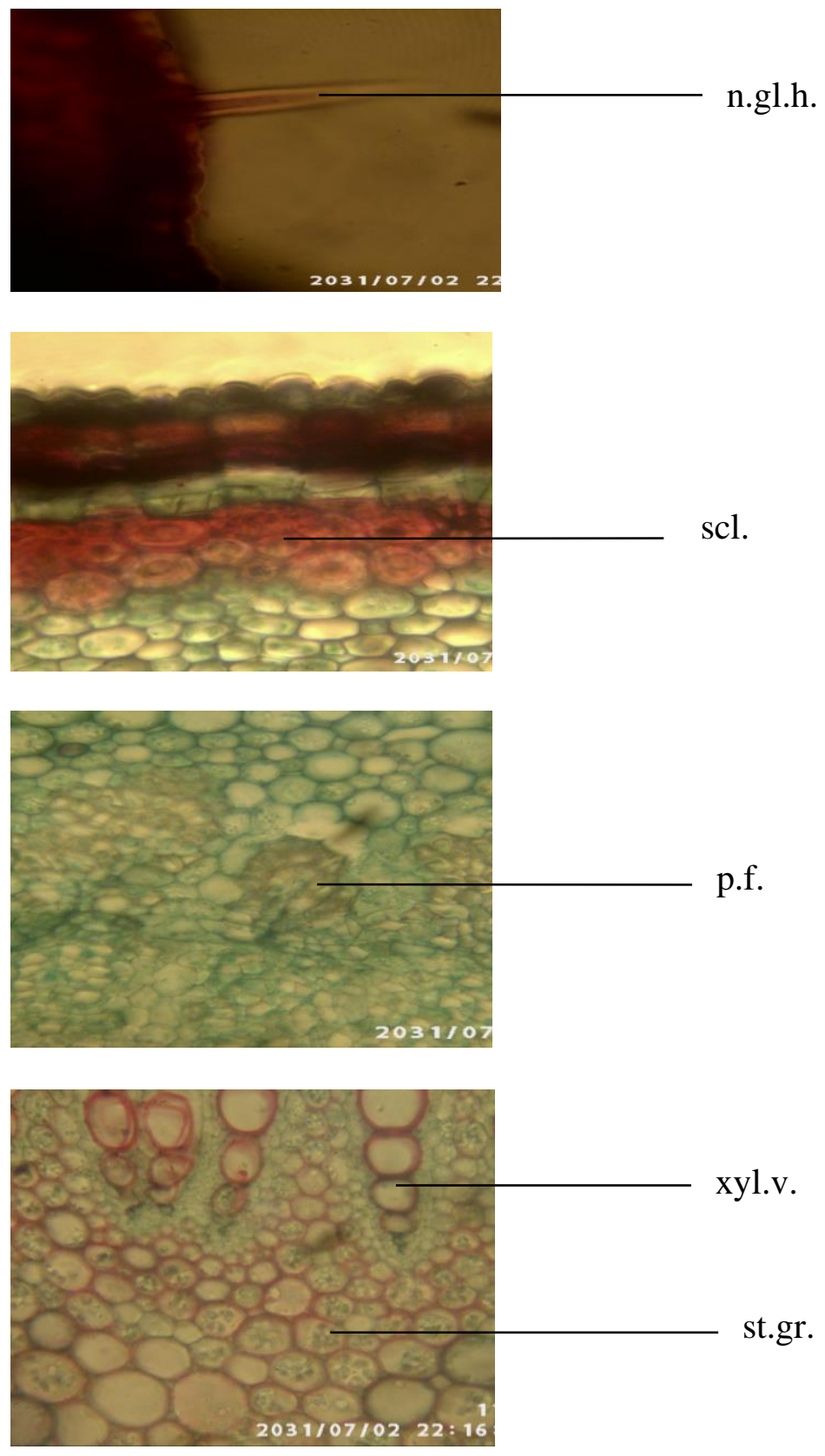

Fig. 6: Photos of detailed T.S. of the stem.

n.gl.h., non glandular hair; p.f., pericyclic fiber; scl., scleride; st.gr., starch granule; xyl.v., xylem vessels. 


\section{The pericycle: (Figs. $5 \& 7$ )}

The pericycle is formed of parenchyma cells alternating with groups of lignified fibers. The fibers are elongated, straight with thick lignified walls, moderately wide lumina and blunt to rounded apices, they measure (212-247-281) $\mu$ in length and (12-14.5-17) $\mu$ in diameter.

\section{The vascular system: (Fig. 5)}

The vascular system consists of continuous ring of phloem, cambium and xylem.

\section{The phloem: (Figs. 5 \& 7)}

The phloem consists of shining thin-walled cellulosic soft elements of sieve tubes and phloem parenchyma. Some laticiferous tubes, which are non-branched with contents that stained yellowishbrown with iodine (T.S), were observed in the phloem. The phloem is separated from xylem by cambial zone.

\section{The cambium: (Fig. 5)}

The cambium is formed of few layers of thin walled subrectangular, tangentially elongated and radialy arranged cellulosic cells.

\section{The xylem: (Figs. 5 \& 7)}

The xylem consists of a comparatively wide zone of lignified thick-walled, radialy arranged elements traversed by uni to biseriate medullary rays. The xylem elements include xylem vessels, wood fibers, wood parenchyma and tracheids. The vessels are arranged in radial rows and show sclariform, spiral and pitted thickening and measure (2239-56) $\mu$ in diameter. The tracheids are elongated with lignified pitted walls, rounded to blunt ends and measure (54-71-88) $\mu$ in length and (9-11-13) $\mu$ in width. The wood fibers have lignified walls, moderately narrow to wide lumina and acute apices some times it may be septated. They measure (160$\underline{203}-245) \mu \square$ in length and (8-1114) $\mu$ in diameter.

Wood parenchyma consists of rectangular to sub rectangular cells with lignified pitted walls. They measure (23-29-35) $\mu$ in length and (21-23-25) $\mu$ in width. The medullary rays are uni to biseriate of sub rectangular cells with thick lignified pitted walls in xylem region, while in the phloem region they are thin-walled cellulosic cells.

\section{The pith: (Fig. 5)}

The pith is formed of a wide central zone of rounded to oval parenchymatous cells. The outer layers of the pith are formed of parenchymatous cells with thick lignified walls which contain starch granules. Starch granules are simple; few are compound of 2-3 components. The inner part of the pith is formed of thin-walled parenchyma cells with intercellular spaces. The cells contain prismatic and cluster crystals of calcium oxalate. The prisms measure (4- $\underline{8.5}$ - 
$13 \mu$ in length and the cluster (812.5-17) $\mu$ in diameter. Several groups of intraxyllary phloem with soft cellulosic elements scattered are at the periphery of the pith.

\section{2- The old stem: (Fig. 4B)}

A transverse section through the old stem is nearly similar to that of young stem (Fig. 4B). However it shows an outer brownish, narrow to moderately wide cork formed of thin suberised and tangentially elongated cells. The stone cells and the vascular system are similar to those of the young stem but more developed.

\section{The powder and isolated elements of stem: (Fig. 7)}

The powdered stem of Ficus pandurata (Hance) has dark green color with a faint odour and bitter acrid taste. The powder and isolated elements of stem are characterized microscopically by the following:

1- Fragments of polygonal, mainly axially elongated epidermal cells with straight anticlinal walls and covered with thick cuticle, stomata are not observed.

2- Unicellular, non-glandular hairs covered with thick cuticle having acute apices, contain brownish matter.

3- Fragments of thin-walled parenchyma cells either from the cortex or the pith, containing prismatic, cluster crystals of calcium oxalate and starch granules.

4- Fragments of pericyclic fibers with straight thick lignified walls moderately wide lumina and blunt to rounded apices.

5- Fragments of lignified xylem vessels with spiral, sclariform and pitted thickenings.

6- Fragments of wood fibers with straight walls, moderately wide to narrow lumina, acute apices and sometime septated lignified walls.

7- Fragments showing lignified and pitted parenchyma cells of the xylem in addition to pitted lignified cells of medullary ray.

8- Fragments of tracheids, with rounded apices and lignified pitted walls

9- Fragments of laticiferous vessels which are simple, nonbranched and containing granular contents, staining yellowish-brown with iodine (T.S).

10- Fragments of lignified sclerides with thick walls and mostly branched narrow lumina.

11- Numerous prisms and clusters of calcium oxalate are scattered.

12- Numerous starch granules are scattered, mainly simple; few are compound of 2-3 components. 


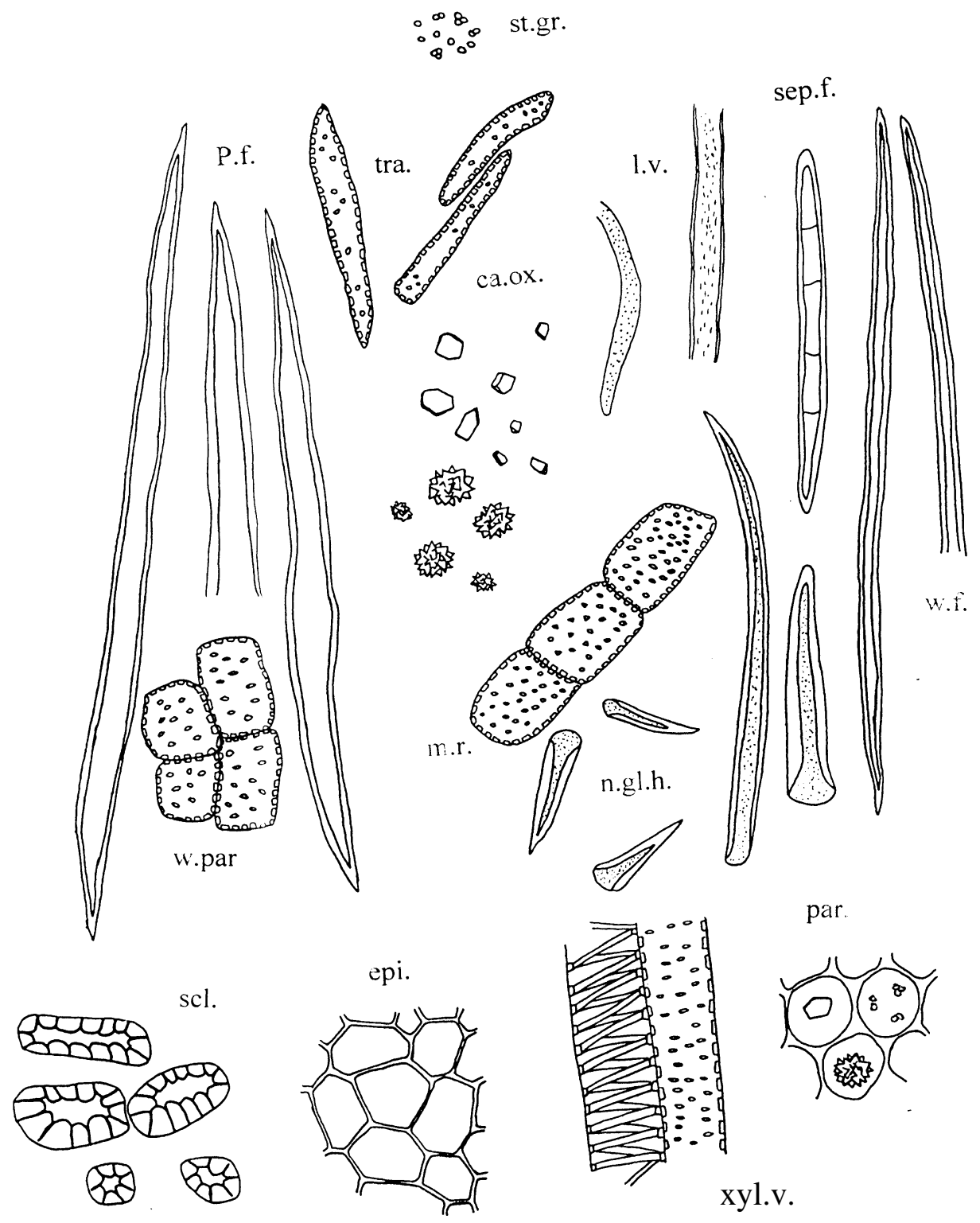

Fig. 7: The powder and isolated elements of the stem X 500

ca.ox., calcium oxalate; epi., epidermis; l.v., laticiferous vessel; m.r., medullary ray; n.gl.h., non glandular hair; par., parenchyma; p.f., pericyclic fiber; scl., scleride (X 625); sep.f., septated fiber; st.gr., starch granule; tra., tracheid; w.f., wood fiber; w. par., wood parenchyma; xyl.v., xylem vessel. 


\section{B- The leaf}

A transverse section through the leaf (Fig. 8A) is somewhat biconvex in outline. It shows a dorsiventral structure with an upper palisade layer formed of two rows which is discontinuous in the midrib region being replaced by 2-3 layers of subepidermal collenchyma cells (hypodermis), 2-4 layers of sclerides and 6-8 rows of collenchyma. In the lower part of the midrib there is another row of collenchyma, 2-3 layers of sclerides and 9-13 layers of collenchyma. The vascular system in the midrib region is represented by a large crescent-shaped dissected vascular bundle accompanied by several additives and inverted smaller ones oriented to form a dissected ring enclosing central parenchyma, the latter contains groups of vasocentric vascular bundles of unequal size, some of which is forming incomplete ring. The pericycle is represented by parenchyma cells interrupted by groups of pericyclic fibers.

\section{The epidermis: (Figs. 8C, D \& 9)}

The upper epidermis in transverse section (Fig. 9) is formed of one layer of isodiametric to sub rectangular thin-walled cellulosic cells covered with thick smooth cuticle; while in surface view (Fig. 8D) they are polygonal, isodiametric to slightly elongated with straight anticlinal walls covered with thick smooth cuticle. The cells measure (15-22-29) $\mu$ in length, (14-18-22) $\mu$ in width and $(7-\underline{8}-9) \mu$ in height. Hairs and stomata were not observed. The upper epidermis is accompanied by 1-2 layers of subepidermal collenchymatous cells (hypodermis) in the midrib region but in the lamina the epidermis is accompanied by 1-2 layers of subepidermal parenchymatous cells (hypodermis). Cystolithic glands were observed beneath the upper epidermis of the lamina which contain calcium carbonate and tested by $\mathrm{HCl}$ (effervescence after addition of $\mathrm{HCl}$ ). The lower epidermal cells (Fig. 8C) are polygonal, nearly isodiametric to elongated with straight anticlinal walls and covered with thick smooth cuticle. Stomata of anomocytic type surrounded by 4-6 cells are present. They measure (1221-30) $\mu$ in length, (7-11.5-16) $\mu$ in width and (4-5-6) $\mu$ in height. The lower epidermis is accompanied by one row of collenchymatous cells.

\section{The mesophyll: (Fig. 8B)}

The mesophyll is heterogenous showing an upper palisade consisting of two layers of columnar cells. The palisade cell measure (1831-43) $\mu$ length. The spongy mesophyll shows somewhat irregular thin walled more or less rounded parenchymatous cells with wide intercellular spaces. 


\section{(A)}
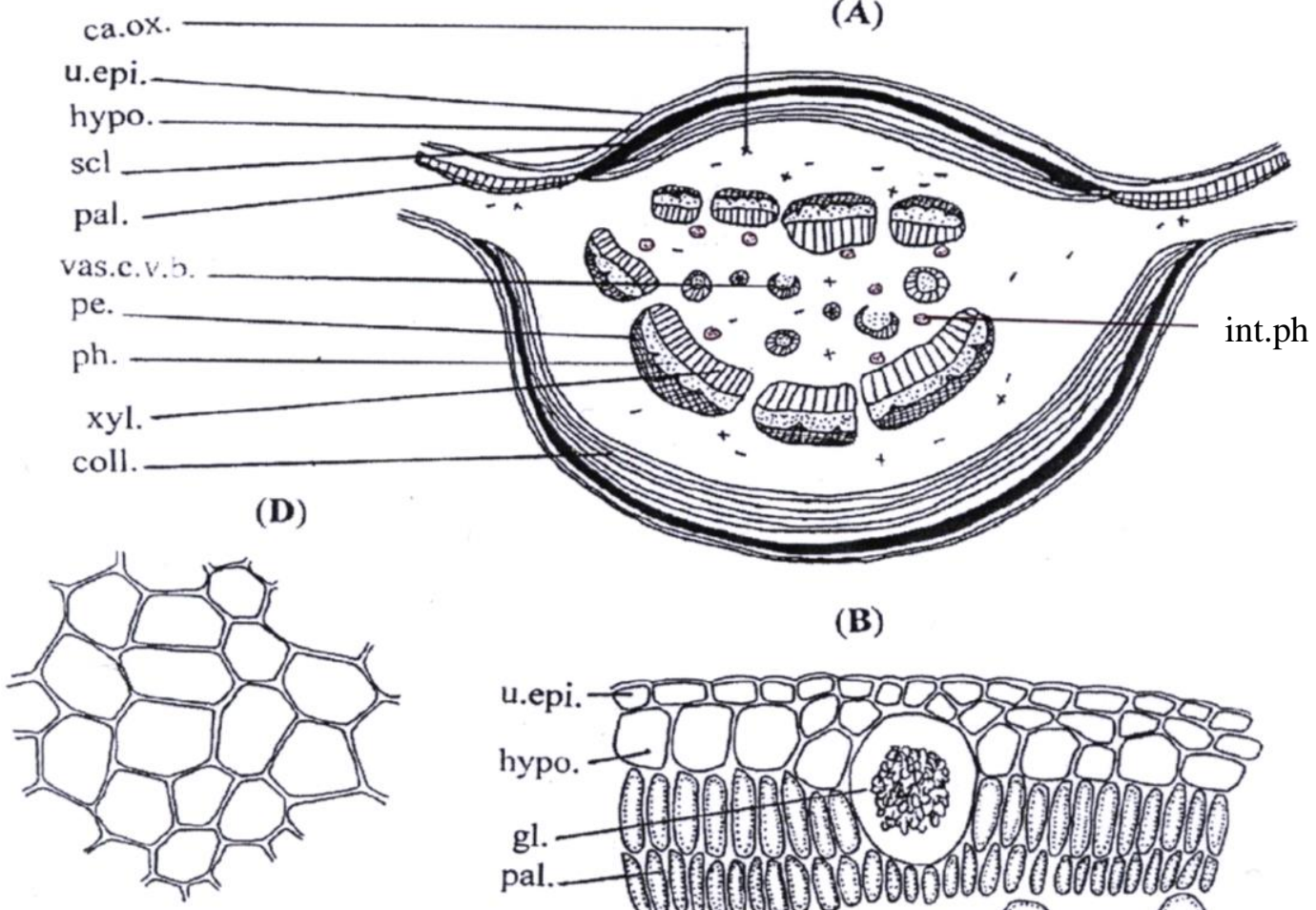

(B)

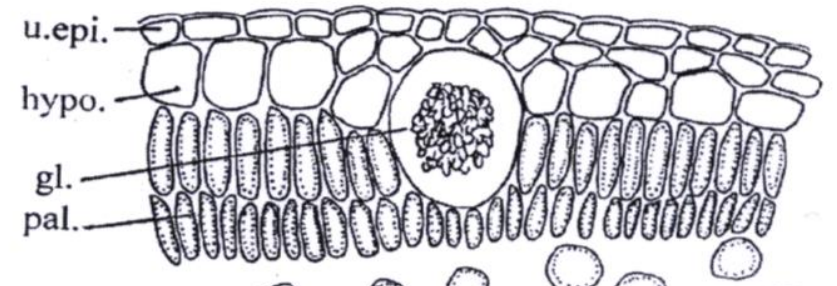

(C)

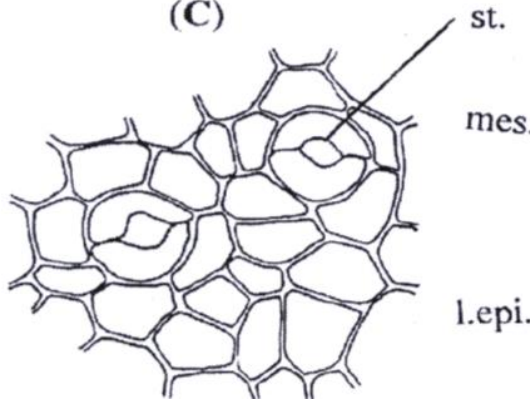

st.

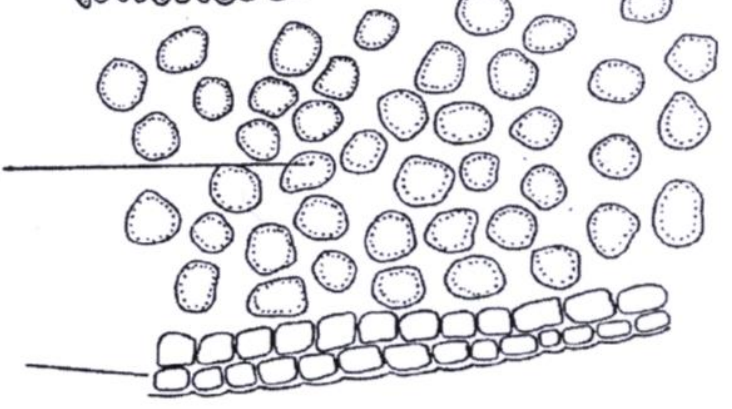

Fig. 8: A. Diagrammatic T.S. of the leaf

X 62.5

B. Detailed T.S. of the lamina

X 312.5

C. Surface preparation of the leaf (lower epidermis)

X 500

D. Surface preparation of the leaf (upper epidermis)

X 500

ca.ox., calcium oxalate; coll., collenchyma; cor., cortex; g., cystolithic gland; hypo., hypodermis; int.ph., intraxylary phloem; l.epi., lower epidermis; l.v., laticiferous vessel; mes., mesophyll; pal., palisade; pe., pericycle; ph., phloem; scl, sclerides; st., stomata; u.epi., upper epidermis; vas. c. v. b.,

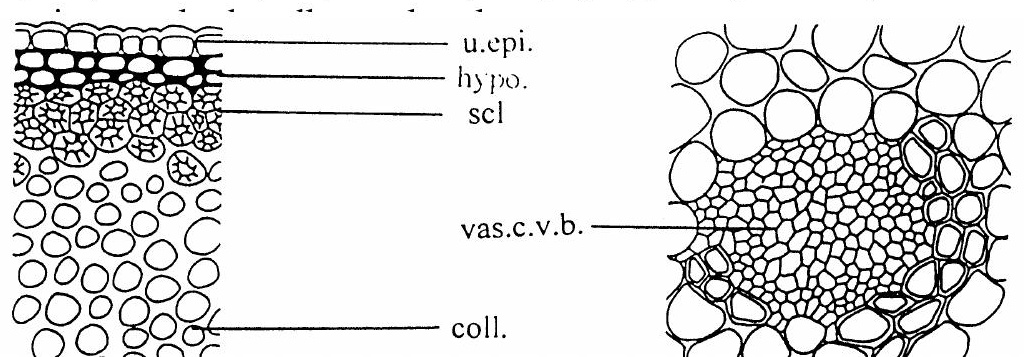


ca.ox

xyl.v.

coll

scl.

hypo.

Fig. 9: Detailed T.S. of the leaf

X 400

ca.ox., calcium oxalate; coll., collenchyma; hypo., hypodermis; l.epi., lower epidermis; l.v., laticiferous vessel; m.r., medullary ray; par., parenchyma; ph., phloem; p.f. , pericyclic fiber; scl., scleride; u.epi., upper epidemis; v., vessel; vas.c.v.b., vasocentric vascular bundle.

(A)

(B) 

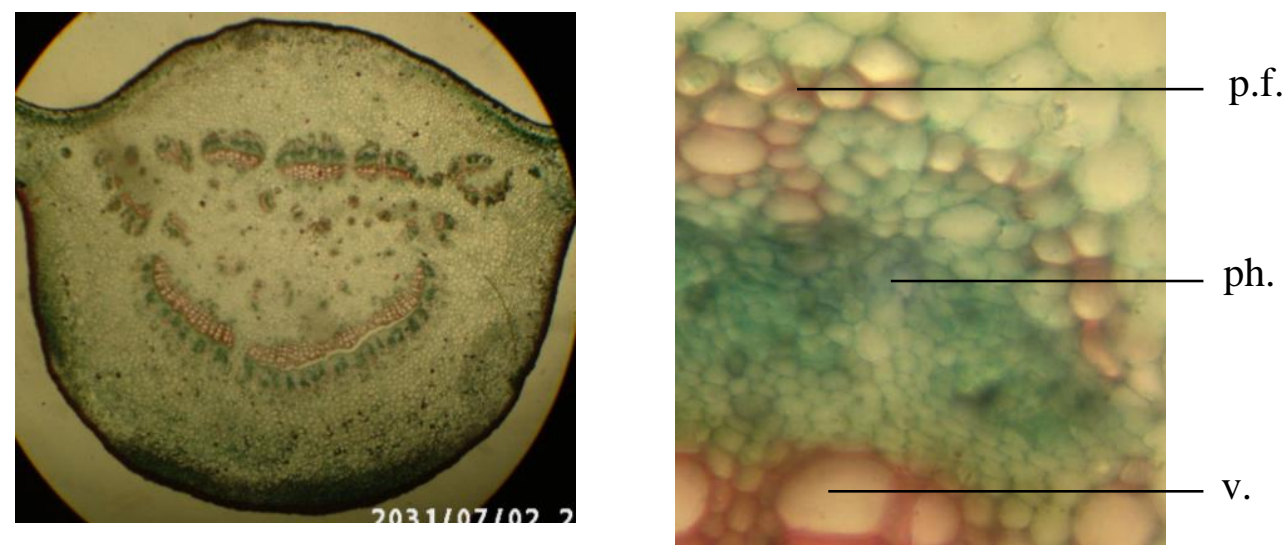

(B)
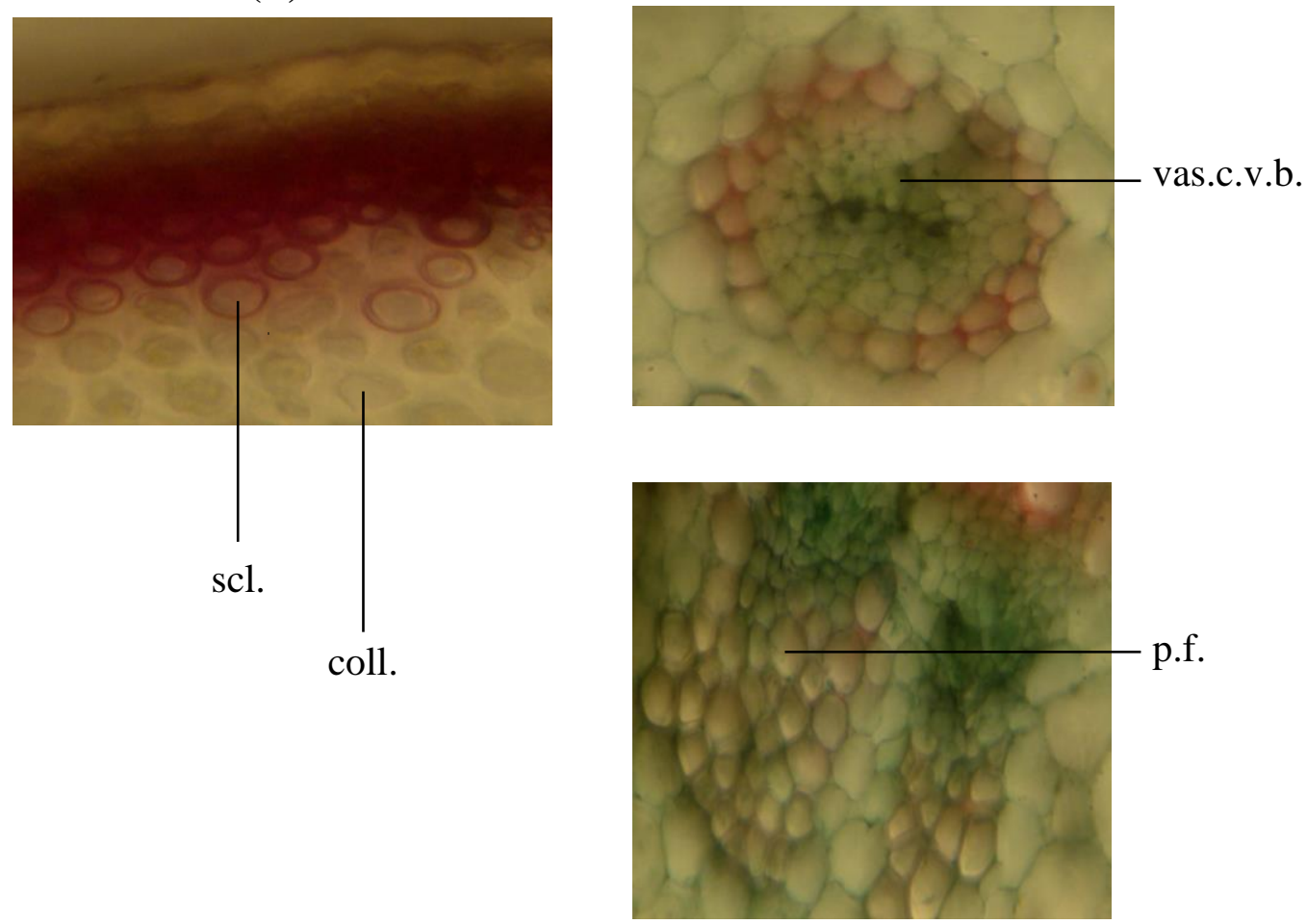

Fig.10: A. Photo of diagrammatic T.S. of the leaf.

B. Photos of detailed T.S. of the leaf.

coll., collenchyma; p.f., pericyclic fiber; ph., phloem; scl., sclerides; v., vessel; vas.c.v.b., vasocentric vascular bundle.

The cortical tissue: (Fig. 9)

The cortical tissue is formed of about 2-4 layers of sclerides with 
thick lignified walls and moderately wide lumina and measure about (9$\underline{14}-18) \mu$ in length and (9-11-12) $\mu$ in width, followed by 6-8 rows of rounded to oval collenchyma cells, in the lower part of the midrib the collenchyma is formed of 9-13 rows of rounded to oval collenchyma cells. The remaining cortical tissue is represented by several layers of wide parenchymatous cells surrounding the vascular bundle. It contains cluster and prismatic crystals of calcium oxalate, the prisms measure (4-9-14) $\mu$ in length and the clusters measure (7-11-15) $\mu$ in diameter. Several groups of intraxyllary phloem with soft cellulosic elements were observed.

\section{The vascular system: (Fig. 9)}

It is represented by a large crescent-shaped main dissected vascular bundle enclosing central parenchyma. Each system surrounded by a pericycle.

\section{The pericycle: (Figs. $9 \& 13$ )}

The pericycle is represented by an arc of pericyclic fibers above the vascular system. Each arc is formed of 3-6 rows of pericyclic fibers. The pericyclic fibers are straight, with lignified moderately thick walls, narrow to moderately wide lumina, acute to rounded apices and measure (114-187-260) $\mu$ in length and (11-14-17) $\mu$ in diameter. The pericyclic fibers penetrate into the phloem region to form an arm into the phloem.

\section{The xylem: (Figs. $9 \& 13$ )}

The xylem region consists of xylem vessels, wood fibers, wood parenchyma, and trachieds and traversed by 1-2 layers of rectangular pitted lignified medullary ray cells. The vessels have spiral, scalariform and pitted thickening measuring (14-18-22) $\mu$ in diameter, the wood fibers (Fig. 13) are few with lignified walls, narrow lumina, rounded to acute apices, and tracheids (Fig. 13) having blunt or pointed end with lignified pitted thickening. The wood fibers measure (32-111-190) $\mu$ in length and (8-11-14) $\mu$ in diameter. The wood parenchyma consists of rectangular to sub rectangular cells with lignified pitted walls, wide lumina and measure (20-29-38) $\mu$ in length and (13-14-15) $\mu$ in diameter.

\section{The phloem: (Fig. 9)}

The phloem is formed of soft thin walled cellulosic elements. Laticiferous tubes were observed which have granular contents, staining yellowish-brown with iodine (T.S). The cambium is not clear.

\section{2- The petiole}

A transverse section through the petiole (Fig. 11A) is nearly similar to that of the stem. It shows an outer epidermis accompanied by 1-2 layers of subepidermal parenchyma hypodermal cells. The cortex contains a ring of 2-4 layers of lignified stone cells, 4-6 layers of 
collenchymatous cells and wide zone of parenchymatous cells.

The pericycle consists of parenchyma cells alternating with groups of pericyclic fibers. The vascular system is formed of a dissected bundles, each consists of radiating xylem and outer phloem enclosing comparatively wide pith. Groups of intra xylary phloem are scattered at periphery of the pith.

\section{The epidermis: (Fig. 11C)}

The epidermis in transverse section (Fig. 11B) consists of one layer of isodiametric to sub rectangular cells. In surface view (Fig. 11C) they are polygonal mostly sub rectangular cells with straight anticlinal walls and covered with smooth cuticle. The cells measure (13-24-35) $\mu$ in length, (13-19-25) $\mu$ in width and (7- $\underline{8-5-}$ 10) $\mu$ in height. Few non-glandular unicellular hairs were observed, stomata are not observed. The epidermal cells are followed by 1-2 layers of hypodermal parenchyma cells similar to those of the stem.

\section{The cortex: (Fig. 11B)}

It consists of a ring of an outer zone of 2-4 layers of lignified thick walled and moderately wide lumina sclerides followed by 4-6 rows of rounded collenchymatous cells. The remaining of the cortex consists of prismatic and cluster crystals of calcium oxalate.

\section{The pericycle: (Figs. 11B \& 13)}

The pericycle is formed of thin walled parenchyma cells interrupted by groups of pericyclic fibers. The pericyclic fibers are similar to those of the stem and measure (113$\underline{186.5}-260) \mu$ in length and (10-1316) $\mu$ in diameter; the fibers have moderately thick lignified walls and narrow to moderately wide lumina with blunt to rounded apices.

\section{The vascular system (Figs. 11B \& 13)}

The vascular system is formed of dissected bundles interrupted by parenchyma cells. The phloem consists of shining thin-walled cellulosic soft elements of sieve tubes and phloem parenchyma. Some non-branched laticiferous tubes with contents stained yellowish-brown with iodine (T.S) are observed. The xylem elements include xylem vessels, wood fibers, wood parenchyma and tracheids. The vessels show sclariform, spiral, and pitted thickening. The vessels measure (25-33-41) $\mu$ in diameter. Wood fibers are fusiform in shape with straight lignified walls, narrow lumina and acute apices. Elongated lignified and pitted trachieds are present. The medullary rays are nogd:hdy unicarriats and formod of

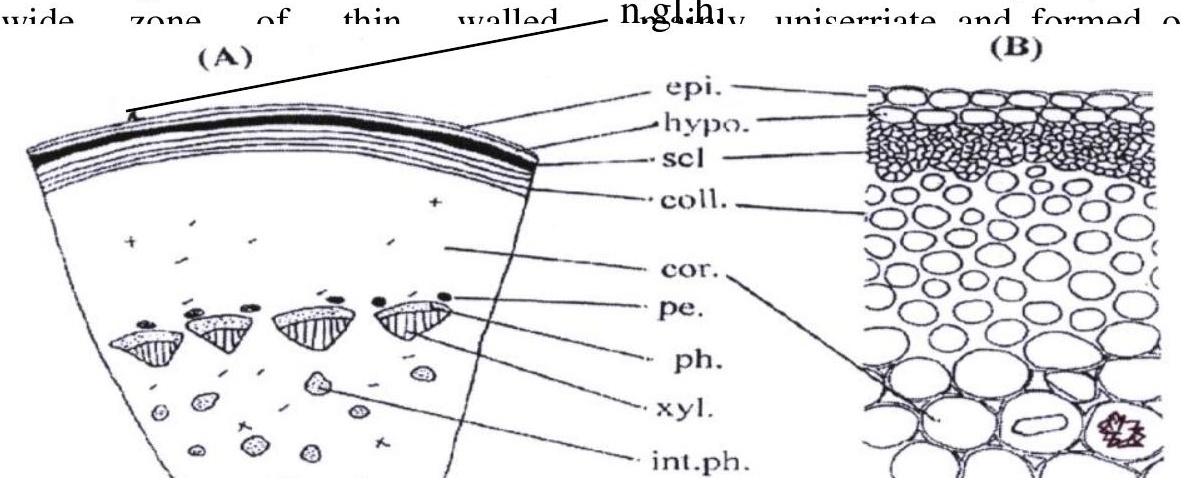


xyl.v.

Fig. 11: A. Diagrammatic T.S. of the petiole

X 62.5

B. Detailed T.S. of the petiole

X 400

C. Surface preparation of the petiole

X 500

ca.ox., calcium oxalate; coll., collenchyma; cor., cortex; hypo., hypodermis; epi., epidermis; int.ph., intraxylary phloem; l.v., laticiferous vessel; n.gl.h., nonglandular hair; par., parenchyma; pe., pericycle; p.f., pericyclic fiber; ph., phloem; pi., pith; scl., scleride; xyl., xylem; xyl.v., xylem vessel. 

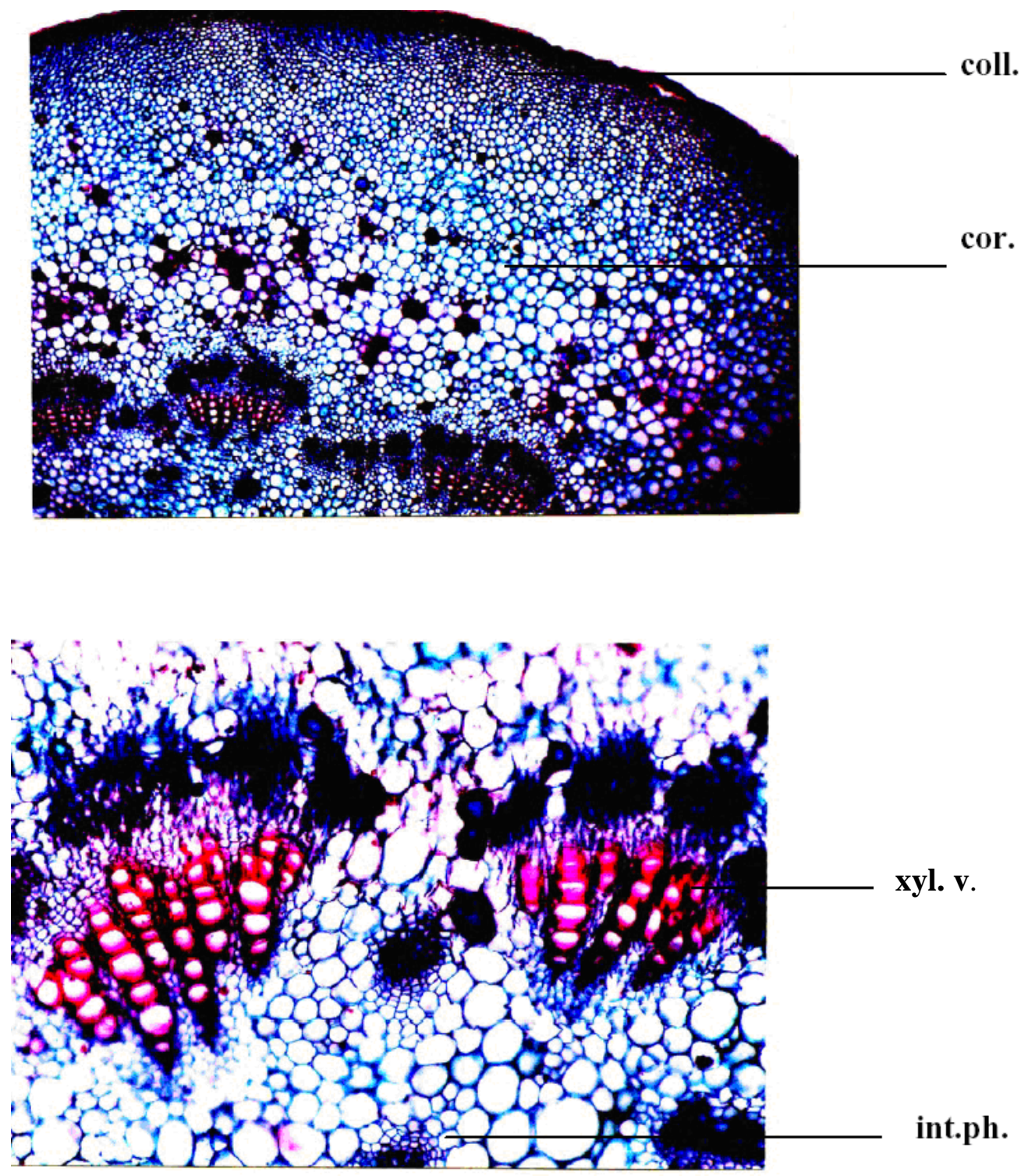

Fig. 12: Photos of detailed T. S. of the petiole.

coll., collenchyma; cor., cortex; int. ph., intraxylary phloem; xyl.v., xylem vessels. 
sub-rectangular, pitted lignified cells in the xylem region but nonlignified in the phloem region. The pith is formed of somewhat rounded to isodiametric, thin-walled parenchyma cells with wide intercellular spaces. The cells contain prismatic and cluster crystals of calcium oxalate. The prisms measure from (4- $\underline{8.5}-13) \mu$ in length and the clusters measure (711-15) $\mu$ in width.

Several groups of intraxyllary phloem with soft cellulosic elements scattered are at the periphery of the pith.

The powder and isolated elements of the leaf: (Fig. 13)

The powdered leaves are darkgreen in color with characteristic odour and bitter acrid taste. The powder and isolated elements are characterized microscopically by the following:

1- Fragments of the upper epidermis of the leaves showing polygonal, nearly isodiametric cells with straight anticlinal walls and covered with thick smooth cuticle. Stomata were not observed.

2- Fragments of the lower epidermis of the leaves showing polygonal, nearly isodiametric cells with straight anticlinal walls bearing anomocytic stomata of 4-6 cells.
3- Fragments of the epidermal cells of the petiole consisting of polygonal to sub rectangular cells covered with smooth cuticle.

4- Unicellular, non-glandular hairs from the petiole are observed covered with thick cuticle and acute apices containing brownish matter.

5- Fragments of the cortical parenchyma cells containing prismatic and cluster crystals of calcium oxalate.

6- Fragments of pericyclic fibers with straight slightly lignified walls, moderately wide lumina and acute apices.

7- Fragments of spiral, sclariform and pitted lignified xylem vessels.

8- Fragments of laticiferous vessels which are simple, nonbranched and containing granular contents, staining yellowish-brown with iodine (T.S).

9- Fragments of wood fibers with straight, slightly thick lignified walls and acute to acuminate apices.

10- Fragments of lignified and pitted parenchyma cells of the xylem,

11- Fragments of tracheids and medullary rays.

12- Numerous scattered prismatic and cluster crystals of calcium oxalate.

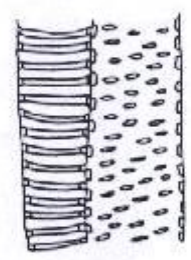

xyl.v.
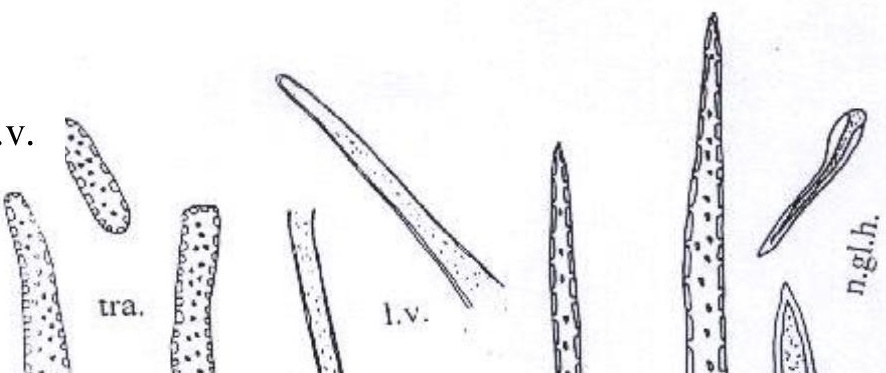
Fig.13: The powder and isolated elements of the leaf X 500

ca.ox., calcium oxalate; epi. , epidermis; l.v., laticiferous vessels; l.epi., lower epidermis; m.r., medullary ray; n.gl.h., nonglandular hair; pal., palisade; par., parenchyma; p.f., pericyclic fiber;scl., scleride; tra., tracheid; u.epi., upper epidermis; w.f., wood fiber; w.par., wood parenchyma; xyl.v., xylem vessels.

\section{C- The Stem Bark}

Micromorphology of the stem bark 
A transverse section through the stem bark (Fig. 14A) shows three distinct regions, the cork, cortex and phloem regions.

The cork consists of several rows of radially arranged tangentially elongated thin-walled cells. The cortex is comparatively wide regions formed of outer 4-7 rows of sclerides followed by thinwalled irregular shaped parenchyma cells containing prisms of calcium oxalate. The cortical tissue interrupted by groups of collenchyma cells. The inner most layer of cortex shows groups of lignified pericyclic fibers. The phloem appears as wide zone consists of phloem parenchyma and phloem fibers, they are traversed by funnel shaped medullary rays.

\section{The cork: (Figs. 14B \& 15)}

The cork layer is formed of several rows (8-13 layers) of radially arranged tangentially elongated, tabular to subrectangular cells with thin walls. The outer rows of the cork contain yellowish brown pigments, while the rest being free of the of the pigments. The cork cells in surface view (Fig. 15), appear polygonal to isodiametric, slightly elongated with straight anticlinal walls, measure (12-18-24) $\mu$ in length, (9-12-15) $\mu$ in width and (6-10-14) $\mu$ in height.

\section{The cortex: (Figs. 14B \& 16)}

The cortex is formed of outer 47 rows of thick-walled lignified stone cells, with narrow to moderately wide lumen, the stone cells measuring (24-34-44) $\mu$ in length and (20-25-30) $\mu$ in width., followed by thin walled, rounded to oval parenchyma cells. Few stone cells are scattered in the cortex which characterized by thick, lignified walls. The parenchyma cells contain prisms of calcium oxalate measure (4- $\underline{8}-12) \mu$ in length and (4-7-10) $\mu$ in width. Groups of rounded to oval collenchyma cells are present in outer cortex.

The innermost layer of the cortex contain few groups of pericyclic fibers

(Figs. 14B \& 15) which have thick lignified walls and they measure up to (235-262.5-290) $\mu$ in length and (11-14-17) $\mu$ in width.

\section{The phloem: (Figs. 14B \& 16)}

The phloem zone is comparatively wide formed of phloem parenchyma and phloem fibers, traversed by funnel shaped medullary rays. The phloem parenchyma consists of rectangular to sub rectangular, somewhat oval thin-walled, non-lignified cells containing prisms of calcium oxalate.

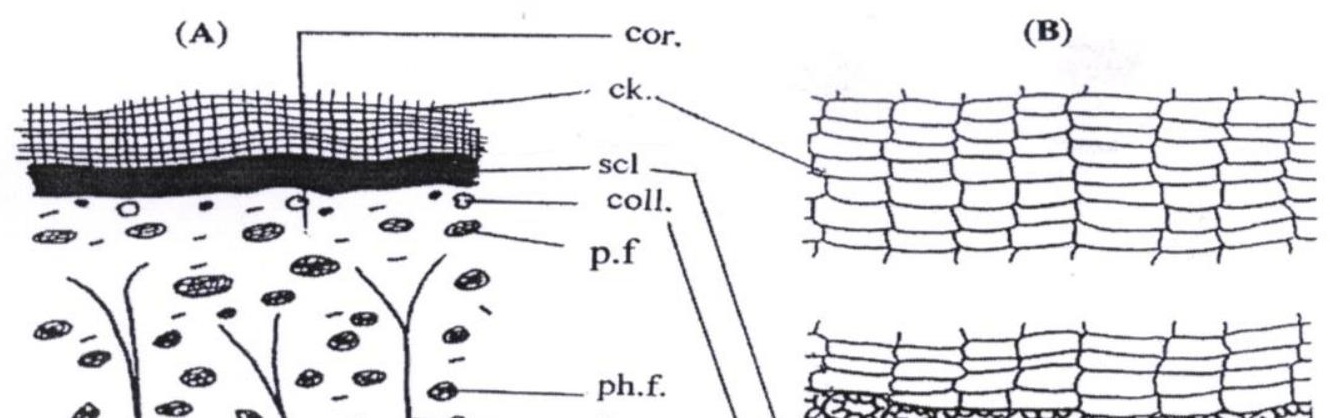




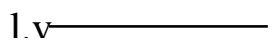

Fig. 14: A. Diagrammatic T.S. of the stem bark X 50

B. Detailed T.S. of the stem bark X 400

ca.ox., calcium oxalate; coll., collenchyma; cor., cortex; ck., cork; 1.v., laticiferous vessel; m.r. , medullary ray; p.f., pericyclic fiber; ph.f. phloem fiber; ph. par., phloem parenchyma; p.f.,pericycle fiber; scl., scleride. 
(B)

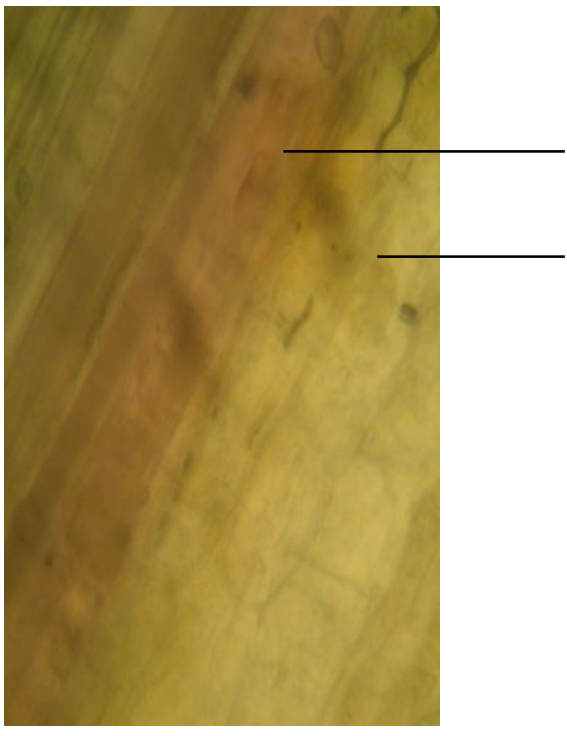

(C)

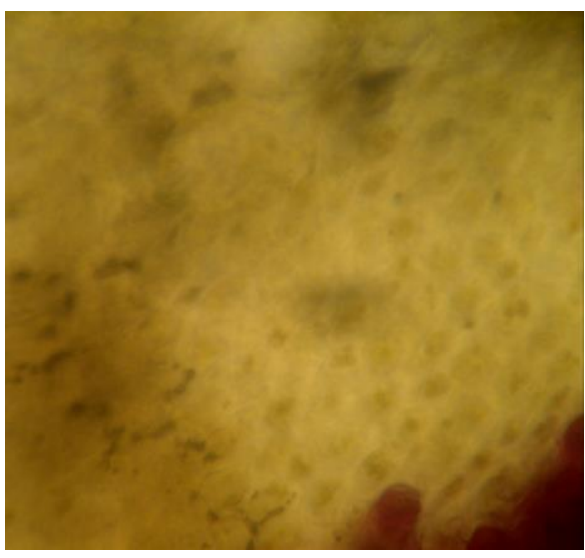

(A)

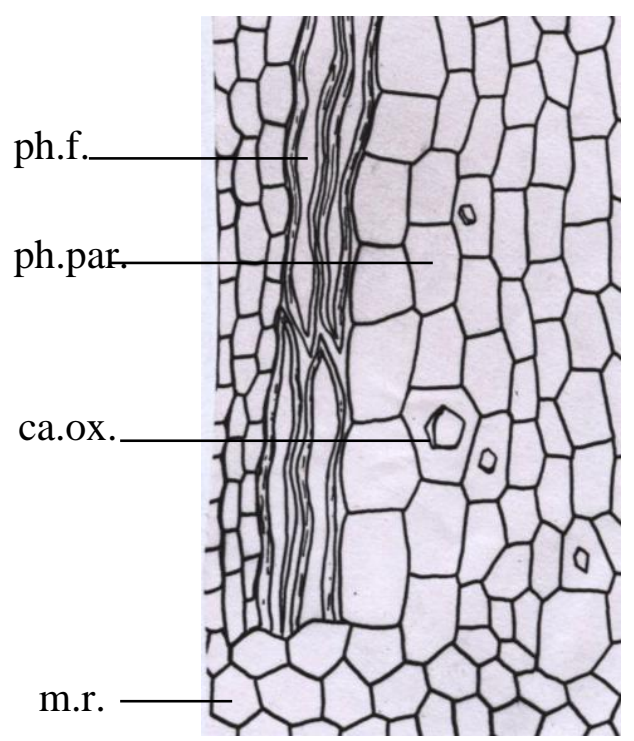

(D)

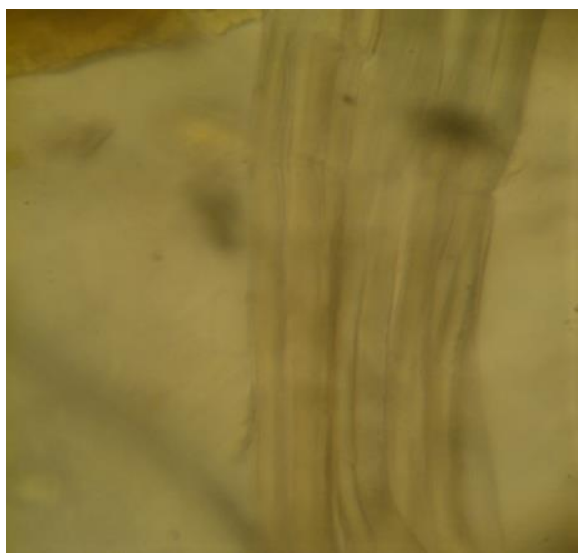

X 500

Fig. 15: A. Detailed L.S. of the stem bark

B. Photo of detailed L.S. of the stem bark.

C. Photo showing collenchyma cells of the stem bark.

D. Photo showing phloem fibers of the stem bark.

ca.ox., calcium oxalate; m.r., medullary ray; ph.f., phloem fiber; ph.par., phloem parenchyma. 


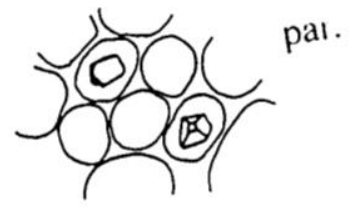

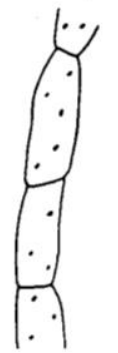

m.r.

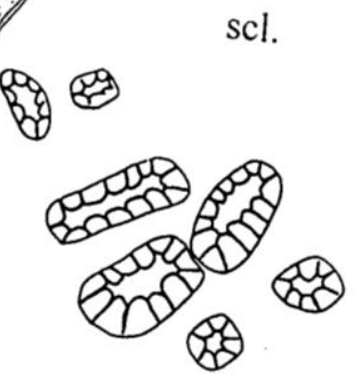

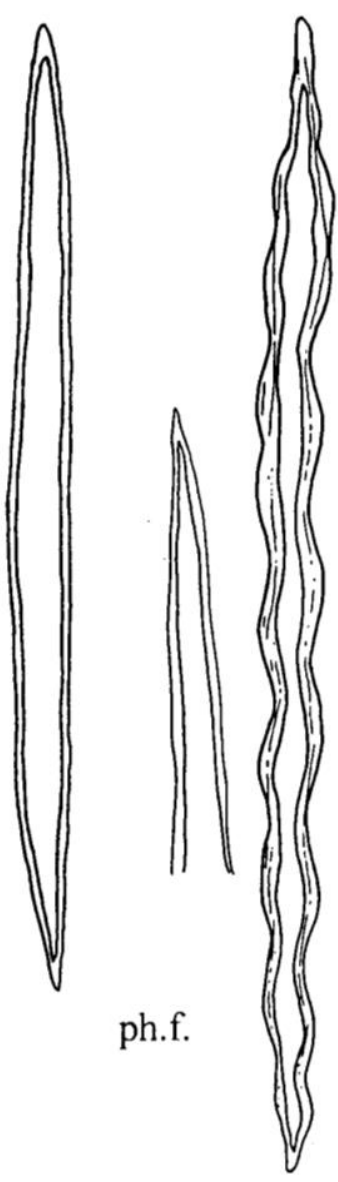

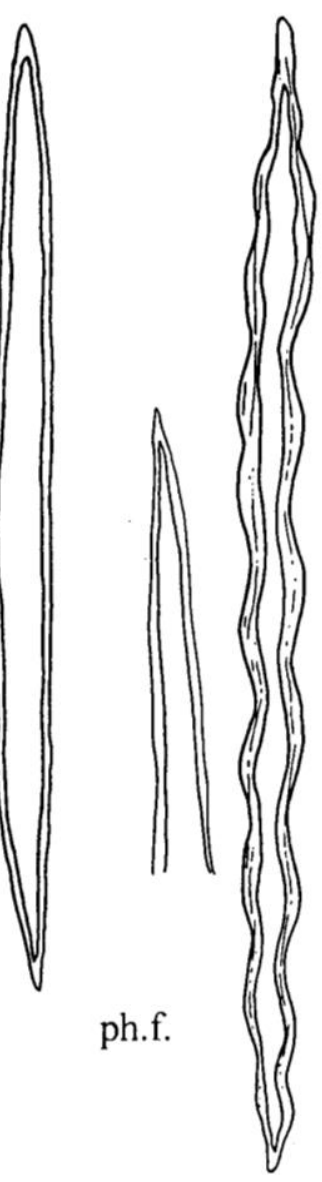

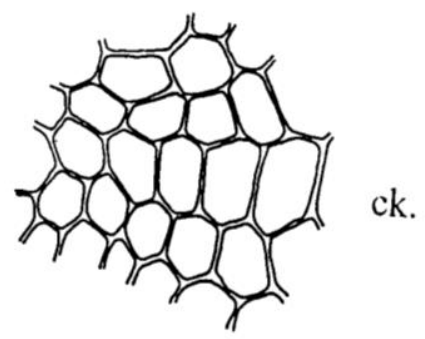

Fig. 16: The powder and isolated elements of the stem bark $\quad$ X 500 ca.ox., calcium oxalate; ck., cork; l.v., laticeferous vessel; m.r., medullary ray; par., parenchyma; ph.f., phloem fiber; p.f., pericyclic fiber; scl., scleride. 
The phloem fibers present as large masses in outer part of phloem, while in the inner part present in small mass or nearly separated. The phloem fibers have thick, slightly lignified irregular walls, narrow to moderately wide lumen and acute to acuminate apices. They measure (275-309363) $\mu$ in length and (11-17-23) $\mu$ in width. Funnel-shaped medullary rays, formed of thin walled elongated parenchyma cells traverse the phloem parenchyma.

\section{The powder and isolated elements} of stem bark

The powdered of stem bark is brownish in colour with bitter taste and faint odour. The powder and isolated elements are characterized microscopically by the following fragments (Fig. 16).

1- Fragments of the cork cells in top view show polygonal nearly isodiametric, thin walled, nonlignified cells with yellowishbrown pigments.

2- Fragments of lignified pericyclic fibers with straight to slightly wavy walls, moderately wide lumen and acute to acuminate apices.

3- Numerous sclerides of different size either isolated or in groups, polygonal, isodiametric, sub rectangular to fusiform shape with thick, pitted, lignified walls and narrow to wide lumina.

4- Fragments of slightly lignified phloem fibers with irregular thick wavy walls, narrow lumina and acute to acuminate apices.

5- Numerous prisms of calcium oxalate are scattered in the field.

6- Fragments of parenchyma cells containing prisms of calcium oxalate.

7- Fragments of laticiferous vessels which are simple, nonbranched and containing granular contents, staining yellowish-brown with Iodine (T.S.).

8- Fragments of subrectangular thin walled parenchyma cells of the medullary ray.

\section{REFERENCES}

1- L. H. Baily, "The Standard Cyclopedia of Horticulture", New York, the MacMillan Co., $11^{\text {th }}$ Edition, 1963, pp. 1229-33.

2- P. Richard Lin. Wunder, "Flora of North America", Oxford University Press, INC., 198 Madison Avenue, New York 10016, 1997, pp. 388-89, 396400.

3- C. R. Metcalf and L. Chalk, "Anatomy of Dicotyledons", the Clarendon Press, Oxford, 11, 1950, pp. 1259-91.

4- L. H. Baily, "Manual of Cultivated Plants", the MacMillan Co., New York, 1958, p. 338.

5- M. P. Singh, M. P. Nayar and R. P. Roy, "Textbook of Forest Taxonomy", Anmol Publication PVT. Ltd., New 
Delhi-110 002, 1994, pp. 44650.

6- G. H. M. Lawrence, "Taxonomy of Vascular Plants", McMillan Co., New York, 1962, pp. 462-64.

7- P. Shukla and S. P. Misra, "An Introduction to Taxonomy of Angiosperm", Vikas Publishing House PVT. Ltd., 1997, pp. 273-77.

8- B. P. Pandey, "Taxonomy of Angiosperm", S. chand and Co. Ltd., Ramnagar, New Delhi$110055,6^{\text {th }}$ Revised Edition, 1997, pp. 148-52.

9- R. R. Kirtikar and B. D. Basu, "Indian Medicinal Plants", M/S Periodical Experts, Delhi-230933 (1975).
10- L. H. Parry and J. Metzger, "Medicinal Plants of East and South Asia", the Mit Press, Cambridge, Massachusetts and London, 1980, pp. 271-75.

11- J. M. Watt and M. G. BreyerBrandwijk, "Medicinal and Posionous Plants of Southern and Eastern Africa", Livingstone Ltd., London, 1962, pp. 773-80.

12- G. F. Edward and W. G. Dennis, Fact sheet ST-254, a series of the Envvironmental Horticulture Department, Florida Cooperative Extention Service, Institute of food and Agriculture Sciences, University of Florida. Publication Date: November 1993.

13- R. L. Riffle, "The Tropical Look", Thames and Hudson Ltd., London, 1998, pp. 176-81. 